\title{
Exchange Rate Fluctuations in Pakistan: Causes and Remedies
}

\author{
SAFIA BEGUM \\ $\mathrm{PhD}$ Scholar and Associate Professor \\ Higher Education Department, Khyber Pakhtunkhwa \\ Email: safiakakakhail@gmail.com \\ MUHAMMAD NAEEM \\ Professor, Department of Economics \\ University of Peshawar \\ AMJAD AMIN \\ Assistant Professor, Department of Economics \\ University of Peshawar \\ Email: amjadamin@uop.edu.pk
}

\begin{abstract}
Exchange rate plays a crucial part in the development of the country and it highlights the prosperity of the country's economy. This study takes various set of determinants, which affect the instability of rate of exchange in the country. This study investigated the relationship of interest rate, inflation, Forex, trade balance and inflow of net foreign capital with exchange rate. The study analyzed the data for the period 1972 to 2014 for Pakistan. Multi-level statistical estimation techniques, VECM, Johnson co-integration, impulse response, variance decomposition and granger causality are applied. The results demonstrated long relationship of interest rate, trade balance, foreign exchange reserve, net foreign capital inflow and exchange rate. The study also confirmed the positive effect of these variables on exchange rate. The study can be especially significant for the government, to make appropriate action to better deal with exchange rate volatility.
\end{abstract}

Keywords: VECM, Granger Causality, Instability of Exchange Rate, Pakistan.

\section{Introduction}

Rate of exchange contributes significantly in the uplifting of growth of economy. There are various determinants which influence the exchange rate of a country. These determinants are widely used throughout the world. Exchange rate fluctuations effect all sectors of economy. Baharumshah \& Wohar (2017) argued that inflation have a profound impact on the rate of exchange . In the similar studies Gosh (2013) stated the importance of trade openness and inflation rate in affecting the exchange rate. Ozkan \& Erden (2015) analyzed 88 countries data and found that output gap, inflation rate and trade openness do affect the exchange rate. However, in the study conducted by Zumaquero (2016), argued that the exchange rate of a country is influenced by regime of a specific country. The study found that mindset of a regime is vital in stabilizing the exchange rate. The study also found that prices of commodities in various regimes, significantly describe the exchange rate volatility in a country. However, in a similar study conducted by Parker and Wong (2014), shows that the rate of exchange of a country is mainly affected by the country export and other factors. Ajao, (2015) argued that the stability of prices, investment and economic stability can be vital in explaining the exchange rate volatility in a country. Many previous findings have highlighted the impact of various determinants on the country exchange rate in developed and developing 
nations. There is ample literature available on the emergence of exchange rate determinants. Devereaux and Engel (2003), assert the importance of the role of monetary policy by keeping in view producers and local currency. Obstfeld (2002) argued the real emergence of macro-economic theory, which further explain EPRT with the help of new model character used by an open currency model. Calderon and Kubota (2018) argued that trade cause volatility, either higher or lower, however they affect the RER. Khin et al. (2017) examined the determining factors of exchange rate for Malaysian economy. The study found that there is positive and substantial relationship between ER, CPI, and Log of ER. The study also concluded that money supply is negatively and significantly associated with ER. Adusei and Gyapong (2017) conducted a study with the help of using partial Least Square Equation model on the data of Ghana, for the period of 1975-2014.The finding of the study found that money supply, current account balance, GDP and GDP growth rate are vital forecasters of the exchange rate. In similar studies Hassan et al. (2017) also explored various contributing factors of exchange rate. The study was based on Nigeria data, for the period of 1989 to 2015. The analysis concluded that fiscal balance, trade openness and oil prices have positive relationship with the country's ER. Alagided and Ibrahim (2017) used data of Ghana for the period 1980 to 2013 and concluded that Government Expenditures, Money Supply and FDI inflows affect the ER in long run. Mpofu (2016) examined the relation between both trade openness and ZAR volatility. Cevik et al. (2016) used GMM model which included 115 countries data for the period 1996 to 2011. Insah and chairak (2013), applied ARDL for the Ghana using data for the period 1980 to 2012 and their finding also revealed the positive impact of government expenditure on exchange rate. They also reported positive association for supply of money, domestic shocks and external dents, which adversely affect the exchange rate. Grydaki and Fontas (2011) analyzed the data of Latin American countries and concluded that fiscal openness, trade openness, inflation and supply of money associated with the exchange rate. The study also asserted that volatile exchange rate regimes also a key elements of exchange rate. In one of the similar kinds of study conducted by Asiama and Kunah (2010), analyzed data of African countries for the period 1980 to 2008 by using Panal co-integration approach found that oil prices, trade openness, and trade are the factors which determines the exchange rate. This study is an attempt to investigate various determinants of exchange rate fluctuations in Pakistan and will find the short run and long run relationship among various factors of exchange rate fluctuations. This study is an attempt in the existing field as it covers the data time period where both democratic and military regimes took place, which show the justification of the volatility in both kinds of regimes. Moreover, the study uses the combination of various estimation techniques, covering the relationship of short term, long term and causality amongst the variables. The study will help the policy makers in finance and fiscal division in framing strategies to take better volatility of the country in order to foster economic growth and favorable exchange rate volatility. Moreover, this study enhances academic contribution, and will be helpful for those who invest in currency.

\section{Methodology}

This study covers the period from 1972 to 2014, representing various mechanism of rate of exchange influenced by the various macroeconomic determinants over the various exchange rate systems, i.e. fixed, floating and managed floating systems. Data obtained from yahoo finance, Business recorder, statistical bureau, state bank of Pakistan and IFS (international financial statistics).

\section{Estimation Techniques}

This study used VECM, Johnsen Co-integration and Granger Causality for the data analysis. ADF test was used for testing the level of stationary, VECM was employed to predict the long run relationship between variables. Granger test was applied to comprehend the uni-directional and bi-direction causality between the variables. Moreover, IRF (Impulse Response Function) and VD (variance decomposition) were applied to dig out the movement proportion of the dependent variable and the response variables. Variable used in this study were, real effective exchange rate (REER) as the dependent variable of the study. Trade balance (TB), Foreign exchange reserve (FER), Inflation rate shown through CPI, rate of interest(IR) and inflow of 
net foreign capital(NFCI). These variables used in this study have also been taken under taken by previous studies in the underlying research area.

Model

$$
\mathrm{REER}_{\mathrm{t}}=\beta_{0}+\beta_{1} \mathrm{CPI}+\beta_{2} \mathrm{IR}+\beta_{3} \mathrm{NFCI}+\beta_{4} \mathrm{FR}+\beta_{5} \mathrm{~TB}+\mu \text {. }
$$

$\beta_{1}$ to $\beta_{5}$ shows the behavior of these variable with REER. $\mu$ shows the standard error, and where as $\beta_{0}$ represents the slope.

\section{Results and Discussion}

\section{Unit Root Test}

Table No. 1 ADF test's Results for unit root

\begin{tabular}{|c|c|c|c|c|c|c|c|}
\hline \multirow[t]{2}{*}{ Variable(s) } & \multicolumn{3}{|c|}{$\begin{array}{c}\text { Results having the constant at } \\
\text { level }\end{array}$} & \multicolumn{4}{|c|}{ Results with constant at $1^{\text {st }}$} \\
\hline & $\begin{array}{l}\text { Critical } \\
\text { value } \\
\text { at } 5 \%\end{array}$ & $\operatorname{ADF}(\mathbf{t})$ & $\mathbf{P}$ & $\begin{array}{c}\text { Critical } \\
\text { value at } \\
5 \%\end{array}$ & $\operatorname{ADF}(t)$ & $\mathbf{P}$ & Conclusion \\
\hline PEER & -2.8756 & -0.9888 & 0.8476 & -2.8765 & -3.5678 & 0.000 & $\mathrm{I}(1)$ \\
\hline Inf & -2.9897 & -3.5463 & 0.0980 & -2.8907 & $-8 ’ 8957$ & 0.000 & $\mathrm{I}(1)$ \\
\hline IR & -3.1985 & -1.7543 & 0.5432 & -2.9211 & -6.8754 & 0.000 & $\mathrm{I}(1)$ \\
\hline TB & -2.9975 & -2.6453 & 0.1231 & -2.9213 & -7.8950 & 0.000 & $\mathrm{I}(1)$ \\
\hline NFCI & -2.9119 & -2.6754 & 0.1009 & -2.9076 & -6.3421 & 0.000 & $\mathrm{I}(1)$ \\
\hline FR & -2.90987 & -2.6470 & 0.3123 & -2.9112 & -7.8967 & 0.000 & $\mathrm{I}(1)$ \\
\hline
\end{tabular}

The result presented in table shows that at level all the variables are non-stationary. The results were placed at order one. So, all the variables are stationary at $1^{\text {st }}$ difference. The stationarity of the data shows that Johansen co-integration, and VECM model should be used for predicting the relationship of short as well as long run.

\section{Lag Selection}

Table 2: VAR Lag Order Selection Criteria

\begin{tabular}{|c|c|c|c|c|c|c|}
\hline Lag & LogL & LR & FPE & AIC & SC & HQ \\
\hline 0 & -577.1213 & NA & 78653 & 33.6754 & 34.7865 & 33.6789 \\
\hline 1 & -517.8209 & 236.564 & 21231 & 29.5324 & 29.7618 & 28.9806 \\
\hline $2 *$ & -456.8970 & 37.6543 & 35102.27 & $26.54217 *$ & 29.7860 & 29.7856 \\
\hline
\end{tabular}

The appropriateness of the results, which is supported by the lag 2, which demonstrate that is justified for the VAR model in unrestricted stable form. VAR is assumed to be a stable, if the roots shows values less than 1 and inside the circle. When one of the majorities of the outcomes i.e. impulse response and SE are not rational, then VAR is not balanced. 
Table No. 3 Unrestricted Co-integration Rank Test

\begin{tabular}{|c|c|c|c|c|}
\hline $\begin{array}{c}\text { Hypothesized No. of } \\
\text { CE(s) }\end{array}$ & Eigenvalue & $\begin{array}{c}\text { Trace } \\
\text { Statistic }\end{array}$ & $\begin{array}{c}\text { 0.05 Critical } \\
\text { Value }\end{array}$ & Prob.** \\
\hline None $*(r=0)$ & 0.92435 & 211.2111 & 95.75366 & 0.0000 \\
\hline At most $1(r \leq 1)$ & 0.64325 & 61.5634 & 68.6735 & 0.0800 \\
\hline At most $2((r \leq 2)$ & 0.62134 & 42.7865 & 48.7864 & 0.0864 \\
\hline At most 3(r $\leq 3)$ & 0.35436 & 27.6534 & 290.7890 & 0.1324 \\
\hline At most 4(r $\leq 4)$ & 0.18792 & 10.6754 & 16.67434 & 0.4217 \\
\hline At most 5(r $\leq 5)$ & 0.03421 & 1.18976 & 4.89763 & 0.45231 \\
\hline
\end{tabular}

In above table the Trace Test result signifies and indicates: 1 co-integrating eqn(s) at the 0.05 level, and while * signifies rejection of the hypothesis at the 0.05 level.

Table No. 4 Unrestricted Co-integration Rank Test (Maximum Eigenvalue)

\begin{tabular}{|c|c|c|c|c|}
\hline $\begin{array}{l}\text { Hypothesized } \\
\text { No. of CE(s) }\end{array}$ & Eigenvalue & $\begin{array}{c}\text { Max-Eigen } \\
\text { Statistic }\end{array}$ & $\begin{array}{c}\text { 0.05Critical } \\
\text { Value }\end{array}$ & Prob.** \\
\hline None **(r=0) & 0.9789 & 89.9087 & 44.7865 & 0.0000 \\
\hline At most $1(\mathrm{r} \leq 1)$ & 0.67865 & 26.8976 & 34.876 & 0.0789 \\
\hline At most $2(\mathrm{r} \leq 2)$ & 0.62347 & 22.7969 & 28.9807 & 0.0908 \\
\hline At most $3(\mathrm{r} \leq 3)$ & 0.35679 & 17.7865 & 22.6754 & 0.1987 \\
\hline At most 4(r $\leq 4)$ & 0.18767 & 10.6754 & 15.7865 & 0.3543 \\
\hline At most $5(\mathrm{r} \leq 5)$ & 0.03246 & 1.08960 & 3.98766 & 0.5432 \\
\hline
\end{tabular}

The result shows that there is only one variable, and results are significant at $5 \%$ level, which confirm the co-integration. The null hypothesis which was no co-integration is thus, rejected. The tract egin value verified the sort of long run relationship. Which means the model will be appropriate if utilized for the long run relationship among the variables. The model would be an asset to denote the long run co-efficient.

\section{Long Run Coefficients}

Table No.5 Long-run Equation

\begin{tabular}{|l|l|l|l|l|l|l|l|}
\hline $\begin{array}{l}\text { Cointegrating } \\
\text { Equation }\end{array}$ & REER (-1) & IR (-1) & INF (-1) & NFCI (-1) & FR (-1) & TB (-1) & C \\
\hline CointEq1 & 1.000 & -6.6745 & -7.7862 & 36.6780 & -8.6098 & 6.8976 & -38.9081 \\
\hline S.E & & $(1.6790)$ & $(0.61206)$ & $(2.8907)$ & $(1.06321)$ & $(0.67890)$ & \\
\hline t-value & & {$[-4.0987]$} & {$[-12.6789]$} & {$[13.6790]$} & {$[-7.9876]$} & {$[14.7653]$} & \\
\hline
\end{tabular}

The above table reported results of the data used for the period 1972 to 2014 for Pakistan, enumerated long run relationship among variable, as all variable used in the co-integration equation has considerable effect on the exchange rate of the country. Interest rate co-efficient signify the negative effect of the interest rate on exchange rate, and other determinants like inflation, and foreign reserve also predicts negative relationship in the long run with exchange rate. However, the NFCI and balance of trade of the country justify a positive relationship in long run with rate of exchange. 
Table No. 6 The Results of VECM

\begin{tabular}{|c|c|c|c|c|c|c|}
\hline $\begin{array}{c}\text { Error } \\
\text { Correction }\end{array}$ & D(REER) & $\mathrm{D}(\mathrm{IR})$ & $\mathrm{D}(\mathrm{INF})$ & $\mathrm{D}(\mathrm{NFCI})$ & $\mathrm{D}(\mathrm{FR})$ & $\mathrm{D}(\mathrm{TB})$ \\
\hline CointEq1 & -0.05674 & -0.02345 & -0.09087 & -0.008976 & -0.041125 & -0.081234 \\
\hline S.E. & $(0.08123)$ & $(0.015643)$ & $(0.03214)$ & $(0.00801)$ & $(0.02340)$ & $(0.01213)$ \\
\hline t-value & {$[-0.78511]$} & {$[-0.8976]$} & {$[-4.11235]$} & {$[-1.2356]$} & {$[-2.77610]$} & {$[-7.32145]$} \\
\hline
\end{tabular}

In above table the VECM results show the correction of the variables towards equilibrium. Model values of error correction lies between 0 to1. The results report negative signs which confirm the speed towards value of equilibrium. In this model the error term corrects for the values of disequilibrium. Which is the result of the various shocks over the period of time. The results predicting the high volatility for both interest rate and inflation.

\section{The Results of Granger Causality}

Table 7 Pairwise Granger Causality Tests

\begin{tabular}{|lcc|}
\hline Null Hypothesis: & F-Statistic & Prob. \\
\hline IR does not Granger Cause PEER & 3.6745 & 0.000 \\
PEER does not Granger Cause IR & 4.6380 & 0.000 \\
\hline INF does not Granger Cause PEER & 3.9807 & 0.000 \\
PEER does not Granger Cause INF & 4.0897 & 0.000 \\
\hline NFCI does not Granger Cause PEER & 6.9087 & 0.000 \\
PEER does not Granger Cause NFCI & 5.7645 & 0.000 \\
\hline FR does not Granger Cause PEER & 4.6789 & 0.000 \\
PEER does not Granger Cause FR & 5.9087 & 0.000 \\
\hline TB does not Granger Cause PEER & 2.7890 & 0.000 \\
PEER does not Granger Cause TB & 3.6574 & 0.000 \\
\hline
\end{tabular}

Granger causality test findings indicate that there is bi-directional cause and effect exist between rate of interest and exchange rate. The result implies that IR significantly affect PEER, and vice versa. Same interpretation for inflation and PEER. Whereas NFCI and PEER also affect each other, thus predicting bidirectional causality among both variables. Same interpretation for variable FR and PEER, and Trade openness and PEER because of the observed bi-directional causality and significant effect each other, with significant probability value at $5 \%$ level.

\section{Conclusions}

Rate of Exchange performs a vital role in the development of the country. This study predicts various set of determinants, which have an effect on the volatility of exchange rate in the country. The research focused the relationship among NFCI (net foreign capital inflow), rate of inflation, interest rate, TB(balance of trade) and FOREX((foreign exchange reserve) with the exchange rate in the country. Data for the period 1972 to 2014 were analyzed using VECM, Johnson co-integration, and granger causality. The outcomes demonstrated long relationship of rate of interest, TB, FOREX, NFCI and rate of exchange. The study confirmed that interest rate and inflation rate negatively affect the exchange rate. These results confirm many previous studies findings (Adusei, M., \& Gyapong, E. Y. 2017). The study, also demonstrated the positive effect of trade openness and NFCI on the rate of exchange of Pakistan . The study reported bidirectional causality between each factor and exchange rate in Pakistan. The same kind of results have been 
confirmed by many other researchers in the same area (Baharumshah, A. Z., Soon, S. V., \& Wohar, M. E., 2017). This study provides enrich updated information for the interested parties like government to strengthen the policy and measures, appropriate form of action to better address the relevant factor that lead to the greater volatility in exchange rates in Pakistan. Future comparative research desperately needed to enhance the understanding more broadly. For example, by cross country comparison between Pakistan and Bangladesh (as both share almost similar exchange rate mechanism), will be more fruitful in understanding the context within which the exchange rate fluctuates.

\section{References}

Adusei, M., \& Gyapong, E. Y. (2017). The impact of macroeconomic variables on exchange rate volatility in Ghana: The Partial Least Squares Structural Equation Modelling approach. Research in International Business and Finance, 42, 1428-1444.

Ajao, M. G. (2015). The Determinants of Real Exchange Rate Volatility in Nigeria. Ethiopian Journal of Economics, 24(2),43-62.

Alagidede, P. \& Ibrahim, M. (2017). On the Causes and Effects of Exchange Rate Volatility on Economic Growth: Evidence from Ghana. Journal of African Business, 18(2), 169-193.

Asiama, J. P., \& Kumah, F. Y. (2010). Determinants of real exchange rate movements: Evidence from a Panel of African Countries (1980-2008). West African Finance and Economic Review, 2(2), 48-88.

Baharumshah, A. Z., Soon, S. V., \& Wohar, M. E. (2017). Markov-switching analysis of exchange rate pass-through: Perspective from Asian countries. International Review of Economics \& Finance, 51, 245-257.

Calderón, C., \& Kubota, M. (2018). Does higher openness cause more real exchange rate volatility? Journal of International Economics, 110, 176-204.

Cevik, E. I., Dibooglu, S., \& Kenc, T. (2016). Financial stress and economic activity in some emerging Asian economies. Research in International Business and Finance, 36, 127-139.

Devereux, M. B., \& Engel, C. (2003). Monetary policy in the open economy revisited: Price setting and exchange-rate flexibility. The Review of Economic Studies, 70(4), 765-783.

Ghosh, A. (2013). Exchange rate pass through, macro fundamentals and regime choice in Latin America. Journal of Macroeconomics, 35, 163-171.

Grydaki, M., \& Fontas, S. (2011). What Explains Nominal Exchange Rate Volatility. Evidence from the Latin American Countries.

Hassan, A., Abubakar, M. I., \& Dantama, Y. U. (2017). Determinants of Exchange Rate Volatility: New Estimates from Nigeria. Eastern Journal of Economics and Finance, 3(1), 1-12.

Insah, B., \& Chiaraah, A. (2013). Sources of real exchange rate volatility in the Ghanaian economy. Journal of Economics and international Finance, 5(6), 232.

Khin, A. A., Wong, H. C., Yean, U. L., Ooi, C. K., \& Bin, R. L. L. (2017). Examining between Exchange Rate Volatility and Natural Rubber Prices: Engle-Granger Causality Test. International Journal of Economics and Financial Issues, 7(6), 33.

Morales-Zumaquero, A., \& Sosvilla-Rivero, S. (2016). A contribution to the empirics of convergence in real GDP growth: the role of financial crises and exchange-rate regimes. Applied Economics, 48(23), 2156-2169.

Mpofu, T. R. (2016). The determinants of exchange rate volatility in South Africa. Economic Research Southern Africa, Working Paper, 604.

Obstfeld, M. (2002). Exchange rates and adjustment: perspectives from the new open economy macroeconomics (No. w9118). National Bureau of Economic Research.

Ozkan, I., \& Erden, L. (2015). Time-varying nature and macroeconomic determinants of exchange rate pass-through. International Review of Economics \& Finance, 38, 56-66.

Parker, M., \& Wong, B. (2014). Exchange rate and commodity price pass-through in New Zealand (No. AN2014/01). Reserve Bank of New Zealand. 